\title{
ANALISIS ELABORATION LIKELIHOOD MODEL DALAM PEMBENTUKAN PERSONAL BRANDING RIDWAN KAMIL DI TWITTER
}

\author{
Tuti Widiastuti \\ Program Studi Ilmu Komunnikasi, Universitas Bakrie \\ Jl. H.R.Rasuna Said Kav. C-22, RT.2/RW.5, Karet Kuningan, Kota Jakarta Selatan, Daerah \\ Khusus Ibukota Jakarta 12940, Indonesia \\ No. Telp. (021) 5261448, Email: tuti.widiastuti@bakrie.ac.id
}

\begin{abstract}
This study sought to look at the fact that twitter can shape one's personal branding, then on the basis of this research is compiled on how the analysis elaboration likelihood model in the formation of personal branding in social media. The method used in this research is quantitative content analysis method. The study population was the whole text or tweets made by Ridwan Kamil through his twitter account (@ridwankamil). This study shows, twitter contents can shape one's personal branding. Establishment of personal branding can be done through posts made in his twitter. The formation of personal branding is seen from the theme of writing, retweet and favorite number, type of writing, the uniqueness of writing and writing direction. Establishment of personal branding is required by a person not only through the writings conveyed through the media, but also the need for real action participation and involvement in community life.
\end{abstract}

Keywords:Elaboration likelihood model, personal branding, twitter.

\begin{abstract}
Abstrak
Penelitian ini bertujuan untuk melihat kenyataan bahwa twitter dapat membentuk personal branding seseorang, melalui analisis elaboration likelihood model yang kemungkinan dalam pembentukan personal branding di media sosial. Metode yang digunakan dalam penelitian ini adalah metode analisis isi kuantitatif. Populasi penelitian adalah seluruh teks atau tweet yang dibuat oleh Ridwan Kamil melalui akun twitter-nya (@ridwankamil) selama tahun 2015. Studi ini menunjukkan, twitter isinya dapat membentuk personal branding seseorang. Pembentukan personal branding dapat dilakukan melalui tulisan yang dibuat dalam twitter-nya. Pembentukan personal branding dilihat dari tema penulisan, retweet dan nomor favorit, jenis tulisan, keunikan menulis, dan tujuan penulisan. Pembentukan personal branding diperlukan oleh seseorang tidak hanya melalui tulisan-tulisan yang disampaikan melalui media, tetapi juga kebutuhan untuk partisipasi tindakan nyata dan keterlibatan dalam kehidupan masyarakat.
\end{abstract}

Kata Kunci: model Elaboration likelihood, merek/citra diri, twitter.

\section{Pendahuluan}

Era teknologi informasi yang diwakili oleh keberadaan Internet saat ini, membawa era baru media dalam masyarakat. Proses evolusi telah terjadi ketika muncul Web 2.0 dengan sistem yang jauh lebih meyakinkan daripada pendahulunya. Teknologi terbaru ini berhasil menciptakan Internet interaktif dan dinamis.Komunikasi dua arah interaksi sangat mendukung antara pengguna. In- teraksi ini kemudian membuat kata lain untuk media baru sebagai media sosial atau media sosial karena keterkaitan yang terjadi antara pengguna. Jaringan media sosial yang menghubungkan pengguna internet di media sosial juga bervariasi.

Menurut Flew (dalam Syaifuddin, 2013: 119) media baru atau new media merupakan sebuah terminologi untuk menjelaskan konvergensi antara teknologi komunikasi 
digital yang terkomputerisasi serta terhubung ke dalam jaringan. Contoh media merupakan media yang sangat baru adalah Internet. Program televisi, jenis film, majalah, buku, surat kabar, dan media cetak lainnya tidak termasuk media baru. Munculnya media baru memiliki dampak yang besar pada kehidupan manusia. Media baru telah secara langsung mengubah pola kehidupan masyarakat, budaya, cara berpikir, dan hampir semua aspek kehidupan manusia.

Walaupun pada tahap awal perkembangannya media baru dipandang terutama sebagai pengembangan media pandang-dengar (audiovisual) yang sudah ada sebelumnya, namun media baru tetap merupakan tantangan bagi produksi distribusi, dan bentuk dasar media pandang-dengar (McQuail, 2011:18).Media baru tidak saja telah menjembatani perbedaan pada beberapa media, tetapi juga perbedaan antara batasan kegiatan komunikasi pribadi dengan batasan kegiatan komunikasi publik.Bahan dan kegunaan media semacam itu dapat dipakai secara bergantian untuk kepentingan pribadi dan publik.Di masa mendatang kenyataan tersebut memberikan pengaruh bukan saja terhadap batasan media yang berbeda, tetapi juga terhadap batasan peran institusi media (McQuail, 2011:17-18).

Sistem komunikasi Internet pada prinsipnya didesain sebagai sebuah sistem narrowcasting, yang mana di satu sisi users mengakses dan memilih informasi yang sesuai dengan kebutuhannya. Di sisi lain, Internet yang awalnya mampu memberikan full service web information, akhirnya menjadi portal yang melayani informasi sesuai fokusnya atau spesialisasi (Hadi, 2011: 236).

Tahun 2004 telah hadir situs jejaring sosial Facebook, dimana pengguna dapat berinteraksi secara bersamaan (real time). Setelah facebook demam, twitter dan kemudian hadir sebagai salah satu situs media sosial.pengguna Motif twitter mengakses cukup beragam, yaitu: penggunaan teknologi terbaru, persahabatan, menjaga popularitas, memperluas pengaruh, membentuk opini publik, dan personal branding.

Indonesia merupakan negara dengan pengguna aktif twitter ketiga terbesar dunia. Dalam rilis Statista disebutkan pengguna aktiftwitterIndonesiaperMei2016mencapai 24,34 juta. Sementara itu, pengguna twitter paling banyak berasal dari Amerika Serikat. Jumlah akun twitter aktif yang berasal dari Negeri Paman Sam itu mencapai 67,54 juta. Selanjutnya, India berada di urutan kedua dengan jumlah 41,19 juta akun twitter yang terdaftar (http://databoks.katadata. co.id/datapublish/2016/11/22/indonesiapengguna-twitter-terbesar-ketiga-di-dunia, 22 November 2016).

Profil demografis mayoritas pengguna media sosial seperti twitter adalah seorang pemuda, yang tinggal di kota-kota besar, telah tingkat pendidikan yang lebih tinggi, tingkat penghasilan yang mapan, dan kelas menengah yang memiliki sikap kritis yang tinggi terhadap berbagai isu daerah dari kehidupan nasional. Kegiatan berinteraksi di media sosial kemudian menciptakan ruang bagi siapa saja untuk menggambarkan dirinya masing-masing atau dikenal sebagai personal branding. 


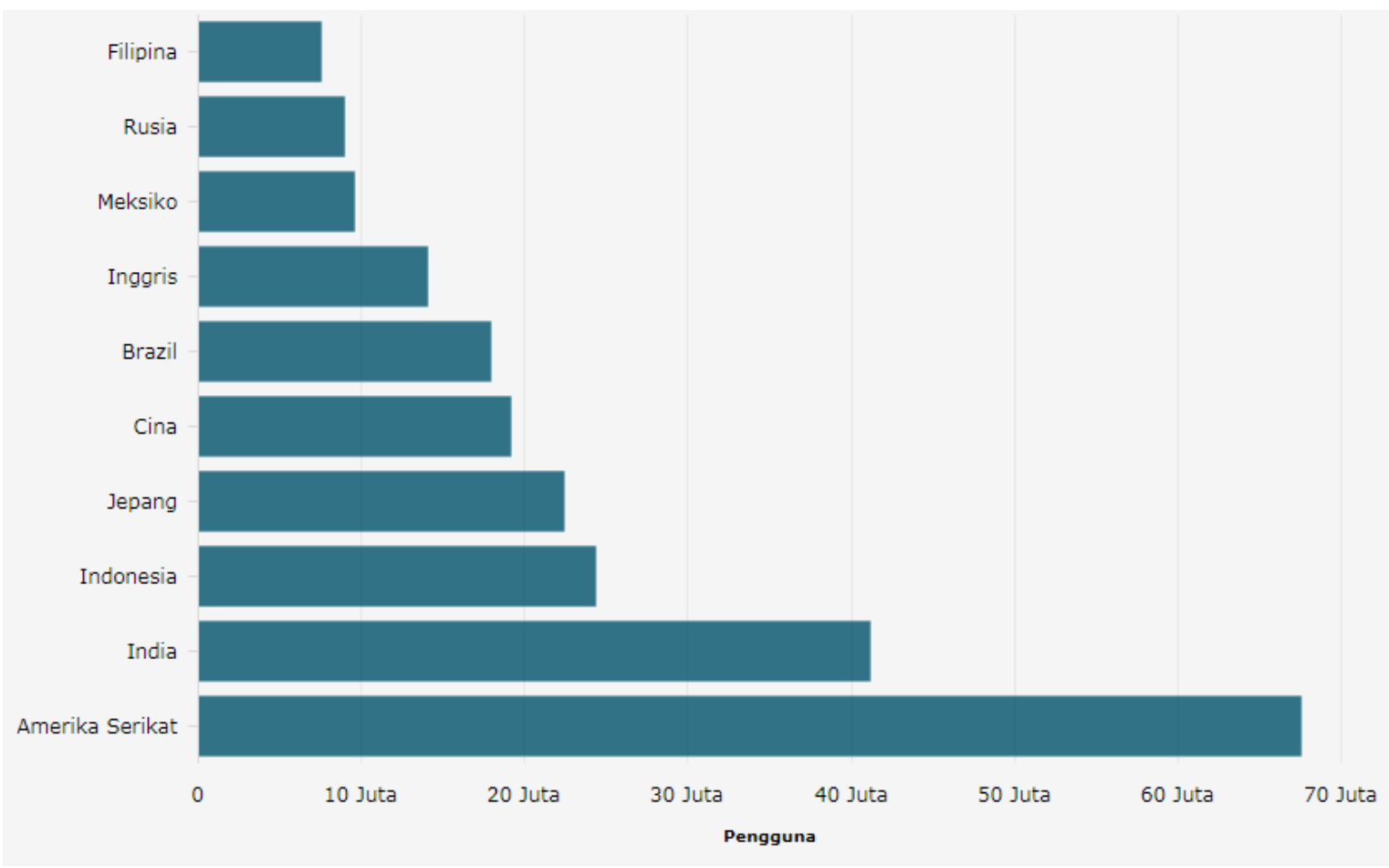

Gambar 1. 10 Negara Pengguna Twitter Terbesar Dunia (Sumber: Databoks, 2016)

Seiring dengan perkembangan teknologi internet dengan media sosial sebagai pendukung di dalamnya, membuat aktivitas personal branding menjadi sangat terbuka. Persepsi akan terbentuk ketika seseorang melihat bagian dari aktivitas personal branding yang media sosial. Ketika media sosial yang belum lahir, personal branding yang dilakukan dengan menggunakan media tradisional hanya satu arah alias komunikasi tidak ada interaksi yang terbentuk di dalamnya.

Ketika era media sosial, komunikasi menggunakan media sosial menjadi lebih interaktif dan langsung.Intensitas komunikasi yang terjadi di dalamnya juga terjadi dalam waktu yang sangat cepat.Hal ini juga dilakukan Bandung Periode Walikota 2013-2018 Ridwan Kamil, akrab disapa "Kang Emil". Twitter media sosial memiliki peran untuk Ridwan Kamil, sebagai orang nomor satu di Bandung untuk berkomunikasi dengan publik, dalam membangun komunikasi dengan masyarakat dan membantunya melakukan personal branding untuk meningkatkan citra dan popularitas di mata publik. Kegiatan Ridwan Kamil menggunakan twitter dan kemudian melakukan intens, setiap kesempatan dalam berbagai kegiatan dan kegiatan instansi swasta, digunakan untuk melakukan memperbarui (update) pesan dalam bahasa twitter disebut "kicauan".

Menurut Juju dan Sulianta (2010: 174), social media merupakan kombinasi antara ruang lingkup elemen dunia maya, dalam produk-produk layanan online seperti blog, forum diskusi, chat room, e-mail, website, dan juga kekuatan komunitas yang dibangun pada jejaring sosial. Apa yang dikomunikasikan dalam memberikan efek "kekuatan" tersendiri untuk akses ke pembangun dalam bentuk teknologi dan juga 'interaksi media dapat dikomunikasikan oleh teks, gambar, foto, audio serta video. Media sosial sebagai perwujudan konsep web 2.0: konten Media dibuat oleh 
masyarakat umum dengan dukungan teknologi (website atau aplikasi web) yang menganut konsep web 2.0. Bentuk fisik dari media sosial: blog, mikroblog, situs jejaring sosial, berbagi foto, video sharing, dan lain-lain.

Twitter adalah jaringan dan microblogging layanan sosial yang memungkinkan pengguna untuk mengirim dan membaca pesan berbasis teks hingga 140 karakter, yang dikelan sebagai kicauan (tweet). Twitter didirikan pada Maret 2006 oleh Jack Dorsey dan diluncurkan situs jejaring sosial di bulan Juli. Sejak twitter diluncurkan menjadi salah satu dari sepuluh situs yang paling banyak dikunjungi dan disebut pesan singkat dari Internet.

Popularitas tinggi twitter menyebabkan layanan ini telah digunakan untuk berbagai keperluan dalam berbagai aspek, misalnya sebagai sarana protes, kampanye politik, sebagai sarana belajar dan media komunikasi darurat. Twitter juga dihadapkan dengan berbagai masalah dan kotroversi seperti masalah keamanan dan privasi pengguna, tuntutan hukum, dan sensor.

Branding dapat diartikan sebagai upaya untuk membuat atau membangun brand atau merek, yang dapat dilakukan oleh siapa saja untuk produk apapun, seperti yang diklaim oleh Terence (2003: 7), komunikator itu, dalam berbagai kapasitas (baik sebagai pengiklan, penjual, pelaku hubungan masyarakat, dan lain-lain, untuk mengembangkan dan menampaikan pesan dari objek yang berbeda. produk, jasa, kegiatan, dan bahkan orangorang.Meskipun istilah tersebut dijelaskan masalah bentu objek beragam, tapi ada satu istilah yang dapat digunakan sebagai ringkasan dari seluruh objek bentuk pemasaran itu, yaitu "merek".
Sedangkan menurut Kertajaya (2004:184) brand sebagai "value indicator", yaitu indikator yang menggambarkan seberapa kokoh dan solid-nya value yang ditawarkan ke pelanggan.Karena merek menggambarkan nilai yang Anda tawarkan, maka itu menjadi alat kunci bagi pelanggan dalam menentukan pilihan pembelian. Karena itu kesalahan besar jika Anda menganggap itu hanya nama merek. Dengan demikian, merek tidak hanya ditujukan untuk produk, tetapi karena manusia juga dapat digunakan sebagai sebuah merek, karena orang juga dapat menghasilkan layanan yang dapat digunakan oleh orang lain. Berdasarkan penelitian ini, peneliti menghubungkan branding dilakukan oleh Ridwan Kamil sebagai karakter yang sangat dikenal oleh masyarakat.

Suatu hal yang sangat penting bagi seorang komunikator sebelum memulai aktivitas komunikasinya, ialah bercermin pada dirinya apakah syarat-syarat yang harus dimiliki seorang komunikator yang handal telah dipenuhi atau belum (Anggraeni, Siswoyo, dan Nurfalah, 2014: 209).Personal branding sebenarnya merupakan bagian dari strategi public relations atau kegiatan public relations yang diterapkan untuk individu. Strategi ini akan berbeda dengan strategi yang diterapkan bagi organisasi. Personal branding adalah kegiatan yang dapat mengontrol perspektif, persepsi orang lain tentang seseorang, sehingga dengan melakukan personal branding maka orang dapat mempengaruhi pandangan orang lain terhadap dirinya sesuai dengan yang dikehendakinya. Seperti yang dikatakan oleh Kertajaya (2004: 184), bahwa brand bukanlah hanya produk saja, tetapi orangpun juga membuat dirinya menjadi sebuah brand, sehingga peneliti akan menjelaskan personal brand. 
Personal branding menjadi fenomena khusus, karena meningkatnya jumlah orang yang menyadari pentingnya merek milik sendiri untuk mendapatkan posisi yang diinginkan. Personal branding merupakan merek dibangun di atas barang manusia dan tidak atau produk yang memiliki identitas yang berbeda.Ada dua hal yang harus dimiliki oleh orang yang ingin menciptakan merek pribadi, yang merupakan entitas yang mudah dikenali dan menjanjikan nilai tertentu.Memahami dari dua hal ini, yaitu entitas (sesuatu yang memiliki keunikan dan berbeda) mudah dikenali sebagai hal yang membedakan merek pesaing lainnya, sehingga memudahkan konsumen atau masyarakat. Sementara menjanjikan nilai-nilai tertentu seperti menjanjikan merek sesuai dengan apa manfaat merek. Dalam membangun merek pribadi, harus memiliki unik dan berbeda dari orang lain, sehingga memiliki manfaat yang dirasakan oleh orang lain.
Salah satu teori komunikasi yang dapat menjelaskan bagaimana strategi komunikator dikomunikasikan terutama untuk konteks dalam berkomunikasi merek adalah Elaborasi Kemungkinan Model. Pada sebuah studi di mana ELM adalah pembujuk dan penonton, analogi di mana merek sebagai pembujuk dan penonton adalah penonton/pengikut twitter akun Ridwan Kamil. Proses untuk mengaktifkan merek yang disebut branding. Proses branding melibatkan komunikasi dan komunikasi dilakukan ada unsur persuasi. Proses kegiatan persuasi yang terjadi adalah bagaimana merek dikomunikasikan kepada masyarakat yang akhirnya dapat mempengaruhi penonton. Kegiatan yang dilakukan bagaimana proses komunikasi proses kognitif yang terjadi sampai pesan diterima secara penuh atau sebagian.

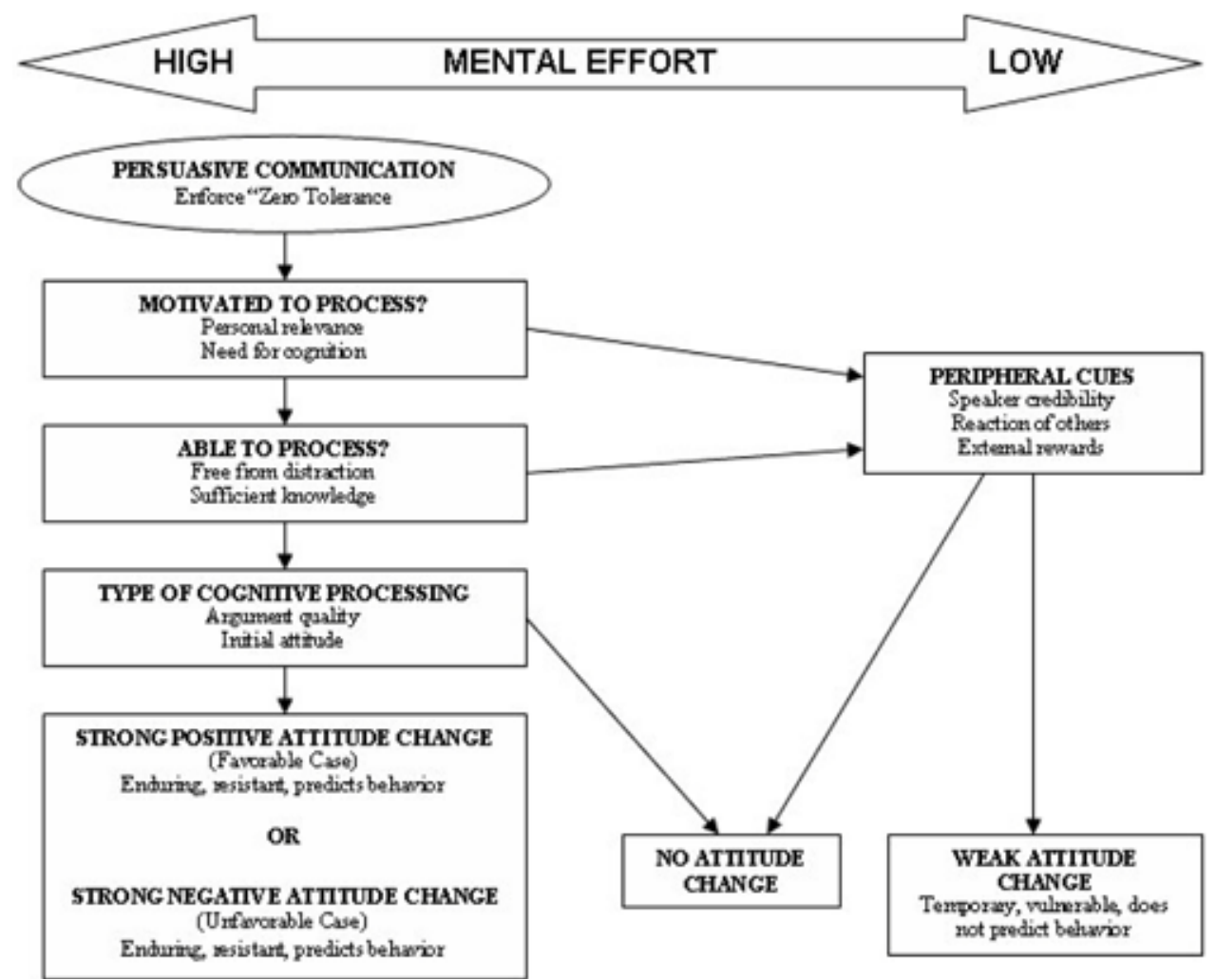

Gambar 2. The Elaboration Likelihood Model

(Sumber: Griffin,2003: 199) 
Petty dan Cacciopo (1986, dalam Griffin, 2010: 206) menjelaskan mengenai perubahan sikap baik secara kognitif, afektif, maupun konatif menggunakan dua rute. Pertama, rute sentral melibatkan elaborasi pesan dan berujung pada kualitas argumen. Sementara rute kedua adalah rute periferal yang hanya mengandalkan petunjukpetunjuk yang memungkinkan penerima pesan mengambil keputusan secara cepat.

Central dengan rute akan menghasilkan dua kemungkinan terjadi, apakah penonton menilai komunikasi persuasif untuk mengekspos menguntungkan atau merugikan. Jika penonton menganggap pesan yang mereka terima manfaat, mereka akan memberikan respon positif terhadap komunikator. Sebaliknya, jika penonton menilai pesan yang diterima dianggap tidak menguntungkan, mereka akan memberikan reaksi negatif. Bertentangan dengan pusat, peripheralberasumsi bahwa perubahan sikap tidak selalu membutuhkan evaluasi informasi yang disajikan oleh media atau sumber lainnya. Sebaliknya bila motivasi atau kemampuan untuk memproses informasi yang relevan tentang masalah ini rendah, persuasi dapat terjadi di peripheral mana proses muncul dengan isyarat sederhana dalam konteks persuasi akanmempengaruhi sikap.

Pemilihan ini memiliki implikasi untuk pembentukan sikap yang terjadi. Pada orang yang memiliki motivasi, kesempatan, dan kemampuan untuk memproses pesan, maka mereka akan menjadi penting dalam memahami informasi atau pesan persuasi. Sementara orang-orang yang memiliki ketiga hal tersebut, akan lebih memilih non-faktor pesan yang akan membantu dia mengambil sikap atau perilaku dengan cepat. Sikap seperti ini tidak kuat dan akan mudah berubah ketika faktor-faktor yang menjadi dasar penentuan sikap juga berubah. Faktor-faktor tersebut dijelaskan dengan istilah peripheral factor, yaitu: authority, commitment, contrast, liking, reciprocation, scarcity, dan social proof.

Pentingnya merek (branding) kini bukan hanya persoalan perusahaan saja. Branding juga diperlukan bagi pembentukan kepercayaan terhadap orang per orang. Personal branding didasarkan atas nilainilai kehidupan anda dan memiliki relevansi tinggi terhadap siapa sesungguhnya diri seseorang. Personal branding akan membuat semua orang memandang anda secara berbeda dan unik. Hal-hal yang tidak konsisten akan melemahkan personal branding, dimana pada akhirnya akan menghilangkan kepercayaan serta ingatan orang lain terhadap diri Anda (McNally \& Speak, 2002: 13).

ModelPDB(positioning, differentiation, brand) merupakan sebuah bagian dari teknik marketing yang bisa juga untuk memasarkan diri seseorang.PDB merupakan penghubung strategy, tactic dan value. Adanya tiga penghubung tersebut, tiga dimensi marketing benar-benar ada linknya. (Kertajaya, 2010:264). Dalam hal ini personal branding, berarti harus jelas penempatan diri seseorang (positioning) dalam pencitraannya mau diarahkan kemana, harus ada alasan mengapa merek tersebut dilahirkan, dan menentukan target market yang akan dicapai. Differentiation yaitu perbedaan yang ada pada diri seseorang 
tersebut, apa yang membuatnya disukai atau hanya sekedar diperhatikan oleh orang lain. Brand adalah value indicator, yang akhirnya kembali lagi ke positioning awal, apabila personal brandkita kuat maka semakin jelas posisi kita di hati masyarakat, karena yang kita jual akhirnya adalah diri kita sendiri.

Penelitian terkaitpenerapan Elaboration Likelihood Model dalam penerapannya di media sosial sebagai salah satu media informasi paling efektif untuk digunakan, selain kulitas pesan dan kredibilitas sumber, pengaruh dari suara mayoritas juga mengambil peranan penting dalam membangun kepercayaan (Pee, 2012). Berdasarkan penelitian yang dilakukan oleh Ginting (2013) terbukti bahwa Twitter memiliki pengaruh yang kuat, signifikan, dan positif dalam membentuk citra. ELM menyimpulkan bahwa kualitas informasi dan petunjuk periferal secara langsung berkaitan dengan perubahan sikap dan kepercayaan (Bhattacherjee dan Sanford, 2006: 814).

Penulis tertarik menjadikan akun Ridwan Kamil menjadi objek penelitian, karena tweet akun@ridwankamil milik seorang pemimpin publik yang aktif mengomunikasikan berbagai topik dari yang serius, humanis, sampai dengan yang santai. Penulis menggunakan Elaboration Likelihood Model (ELM) dalam menganalisis bagaimana akun twitter dapat berperan dalam pembentukan personal branding. Pesan dikomunikasikan dengan strategi dan jalur persuasi yang tepat, maka hasilnya diharapkan akan cocok dengan tujuan. Berdasarkan ELM, akan ada dua kemungkinan yang terjadi pada akun twitter-nya Ridwan Kamil, keberhasilan atau kegagalan media sosial menjadi alat untuk pembentukan personal branding. Model tersebut juga menjelaskan bagaimana membentuk sikap dengan memproduksi komunikasi yang persuasif.

Menurut Lien (2001: 301), ELM adalah mengenai proses yang bertanggung jawab atas terciptanya komunikasi persuasif dan kekuatan dari sikap yang dihasilkan dari proses komunikasi tersebut. Kaitannya dengan citra, ELM kerap digunakan dalam menganalisis komunikasi persuasif salah satunya adalah bagaimana brand ambassador dapat mempengaruhi brand image.Hal tersebut kemudian peneliti terapkan ke level yang lebih besar dalam lingkup personal branding.

\section{Metode Penelitian}

Metode yang digunakan dalam penelitian ini adalah metode analisis isi kuantitatif.Menurut Krippendorff (2006: 8) metode analisis isi merupakan salah satu teknik penelitian yang paling penting dalam ilmu-ilmu sosial.Analisis isi berusaha memahami data bukan sebagai kumpulan peristiwa fisik, tetapi sebagai gejala simbolik dan mendekati analisisnya dengan rendah hati terhadap makna dalam suatu pesan.

Populasi penelitian ini adalah keseluruhan tulisan atau kicauan yang dibuat oleh Ridwan Kamil melalui akun twitternya (@ridwankamil). Sampel yang diambil ada dalam akun twitter Ridwan Kamil sebanyak 100 tulisan atau kicauan (tweets) sepanjang tahun 2015. Dalam penelitian ini, peneliti menggunakan teknik purposive sampling. Teknik ini mencakup seleksi atas 
dasar kriteria-kriteria tertentu yang dibuat peneliti berdasarkan tujuan penelitian. Biasanya teknik purposive sampling dipilih untuk penelitian yang lebih mengutamakan kedalaman data daripada untuk tujuan representatif yang dapat digeneralisasikan (Kriyantono, 2007:154-155).

Penelitian ini berusaha melihat peranan tweet Ridwan Kamil di media sosial Twitter dalam kaitannya dengan pembentukan personal branding berdasarkan prinsip Elaboration Likelihood Model (ELM). Penelitian kemudian berusaha menjabarkan bagaimana gambaran deskriptif mengenai kategori penelitian yang dibagi menjadi: 1) Tipe Argumen, tipe yang direpresentasikan dengan: argumen yang menghasilkan respon kognisi yang bersifat strong arguments, neutral arguments, dan weak arguments. 2) Isi (tema) Kicauan, isi atau tema kicauan disajikan dalam pemilihan konsen pesan, berupa: moral, politik, pencitraan Islam, toleransi, partisipasi. 3) Personal Branding, kegiatan personal branding ditunjukkan pada aktivitas akun twitter berupa positioning, differentiation, dan brand.

\section{Hasil Penelitian dan Pembahasan}

Muhammad Ridwan Kamil, S.T, M.U.D (lahir di Bandung, Jawa Barat, 4 Oktober 1971) adalah walikota Bandung periode 2013-2018. Sebelum menjadi pejabat publik, pria berjuluk "Kang Emil” memiliki karir sebagai arsitek dan dosen paruh waktu di Institut Teknologi Bandung.Emil adalah anak dari pasangan Atje Misbach Muhjiddin dan Tjutju Sukaesih. Pada tahun 2013 Emil profesional dicalonkan oleh PKS dan Gerindra sebagai walikota Bandung, dibantu oleh Oded Muhammad Danial sebagai calon wakil walikota. Dalam Rapat Pleno Komisi Pemilihan Umum Kota Bandung pada 28 Juni 2013, pasangan pemenang dari tujuh pasang lainnya dengan meraih 45,24\% suara sehingga pasangan Ridwan Kamil dan Muhammad Danial Oded ditetapkan menjadi pemenang dalam umum pemilihan walikota Bandung pada tahun 2013.

Ridwan Kamil juga dikenal sebagai sangat aktif di media sosial, khususnya melalui@ridwankamil akun twitter-nya. Melalui komunikasi media sosial ini dengan warga Bandung Ridwan Kamil. Tidak hanya itu, hal itu juga memerlukan lembaga di kota untuk memiliki akun twitter sebagai sarana komunikasi dengan warga Kota Bandung. Ridwan Kamil melalui media sosial juga menyebarkan program yang dibuat oleh Pemerintah Kota Bandung.

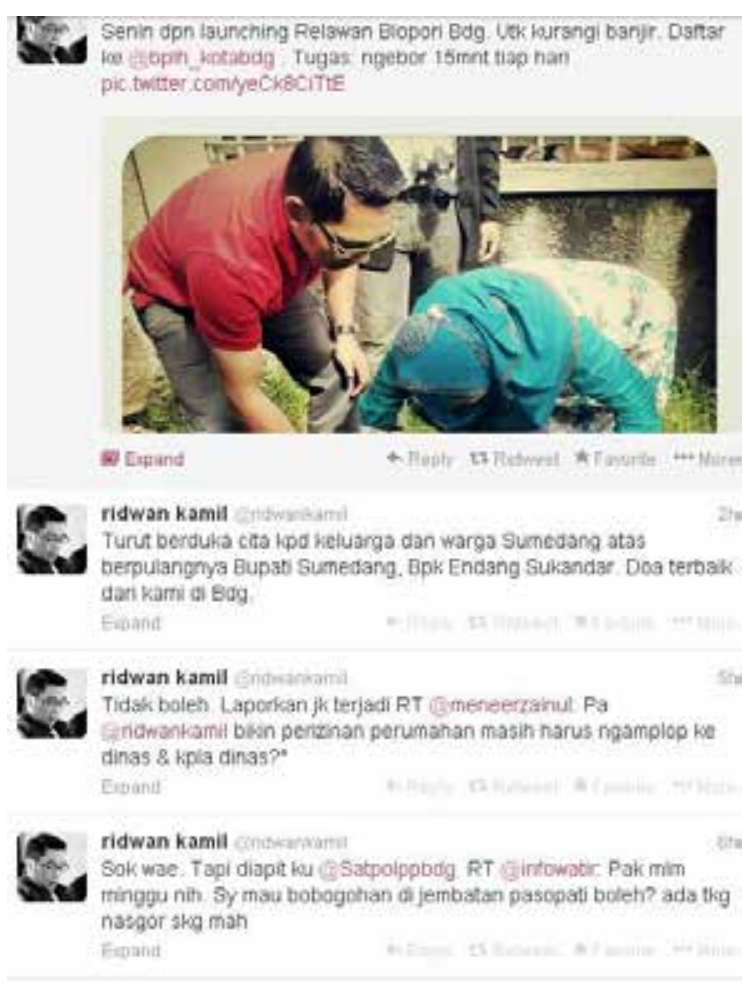

Gambar 3. Tampilan Twitter Ridwan Kamil 


\section{Analisis Tipe Argumen}

Tipe argumen yang terdapat dalam kicauan twitter yang dibuat oleh Ridwan Kamil dikelompokan atas argumen yang kuat, netral, dan lemah. Berdasarkan hasil penelitian didapatkan data yang dapat dilihat pada Gambar 4.

Gambar 4 menunjukkan bahwa argumen yang kuat/strong arguments (52\%) menjadi tipe argumen yang mendominasi yang terdapat dalam akun twitter Ridwan Kamil. Argumen yang kuat menciptakan respon dan komentar yang positif dari followers. Namun argumen yang lemah/weak arguments (30\%) juga banyak terdapat dalam akun twitter Ridwan Kamil, yaitu argumen yang menciptakan respon serta komentar yang cenderung negatif dari followers. Berdasarkan data tersebut maka dapat diartikan bahwa respon dan komentar positif lebih banyak muncul dalam akun twitter Ridwan Kamil, dibandingkan respon dan komentar yang negatif maupun yang netral.

Tipe argumen dapat dikelompokkan berdasarkan tiga kriteria utama, antara lain:

a. Strong Arguments, yaitu argumen yang menciptakan respon kognisi positif di dalam pikiran followers juga secara positif mempengaruhi keyakinan mereka dengan pandangan-pandangan dari komunikator.

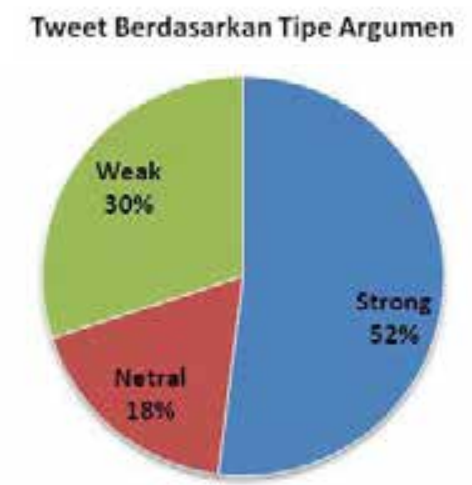

Gambar 4. Tweet berdasarkan tipe argumen b. Neutral Arguments, yaitu argumen yang menghasilkan respon kognisi yang tidak berkomitmen, tidak berpihak, dan tidak memilih dari followers.

c. Weak Arguments, yaitu argumen yang menghasilkan respon kognisi negatif terhadap pesan persuasif.

Kualitas argumen dan kredibilitas sumber merupakan sarana konstruk dari rute sentral dan peripheral dari ELM. Proses tersebut kemudian diolah dengan dikaitkan berdasarkan manfaat yang diterima dalam pembentukan sikap sebagai dasar dari penerimaan pesan. Proses argument tersebut mengevaluasi bagaimana proses persuasi dibedakan berdasarkan keahlian seseorang di bidang isu publik dan relevansi pekerjaan terhadap penerapan informasi melalui twitter. Selain itu, tingkat stabilitas dari tiap rute terhadap efek akhir, yang berupa kemauan untuk berargumen, dapat menjaga stabilitas dari pengaruh kepada followers dapat bertahan.

\section{Analisis Tema Tulisan}

Tema tulisan yang ada dalam kicauan twitter yang dibuat oleh Ridwan Kamil dikelompokan atas tema politik, moral, pencitraan Islam, toleransi, dan partisipasi. Berdasarkan hasil penelitian didapatkan data sebagai berikut:

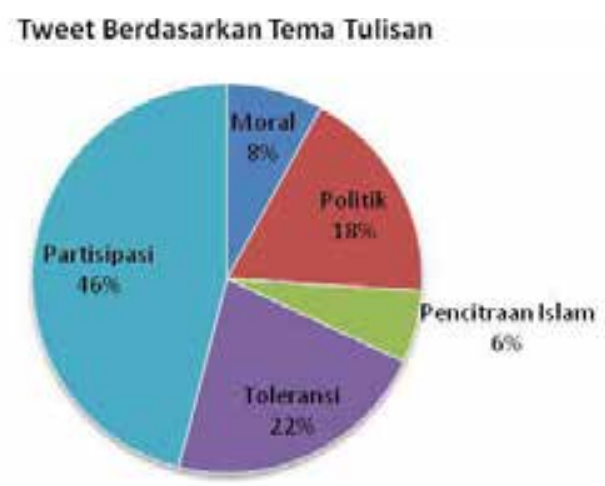

Gambar 5. Tweet berdasarkan tema tulisan 
Isi (tema) kicauan di Ridwan Kamil di akun twittwer-nya dibedakan berdasakan isu: (1) Moral, yaitu didefinisikan sebagai kualitas dalam perbuatan manusia yang menunjukkan bahwa perbuatan itu benar atau salah, baik atau buruk. Moralitas mencakup tentang baik buruknya perbuatan manusia. Dalam konteks ini, tulisan bermuatan moral, jika membicarakan tentang baik dan buruk, benar dan salah; ajaran-ajaran tentang kebaikan; bersifat subyektif dan relatif; bersumber dari agama, aturan, tradisi dan ideologi. (2) Politik, yaitu mempelajari negara, tujuan-tujuan negara dan lembagalembaga yang akan melaksanakan tujuan itu; hubungan antara negara dengan warga negaranya serta dengan negara-negara lain. (3) Pencitraan Islam, yaitu tulisan atau isi pesan yang bermuatan mengenai Islam; tidak hanya yang bermuatan positif, tapi juga di luar muatan tersebut. (4) Toleransi, adalah istilah dalam konteks sosial, budaya dan agama yang berarti sikap dan perbuatan yang melarang adanya diskriminasi terhadap kelompok-kelompok yang berbeda atau tidak dapat diterima oleh mayoritas dalam suatu masyarakat. (5) Partisipasi, yaitu pengambilan bagian atau keikutsertaan; partisipasi adalah suatu keterlibatan mental dan emosi seseorang kepada pencapaian tujuan dan ikut bertanggung jawab di dalamnya.

Gambar 5 menunjukkan bahwa partisipasi (46\%) menjadi tema tulisan terbanyak yang terdapat dalam akun twitter Ridwan Kamil. Partisipasi merupakan keikutsertaan Ridwan Kamil dalam berbagai kegiatan dinas baik itu di dalam maupun di luar Kota Bandung. Ridwan
Kamil juga berpartisipasi dalam kegiatan lain seperti kegiatan sosial, keagamaan, pendidikan, dan sebagainya. Tema pencitraan Islam dalam akun twitter Ridwan Kamil merupakan tema yang terkecil $(6 \%)$ frekuensinya. Tulisan pencitraan islam yang dimaksud dalam penelitian ini adalah tulisan atau isi pesan yang bermuatan pencitraan terhadap Islam. Tidak hanya yang bermuatan positif, tapi juga di luar muatan tersebut.

Berdasarkan data tersebut maka bisa diartikan bahwa Ridwan Kamil dalam memposting tulisan lebih banyak menonjolkan pada partisipasi atau keikutsertaan Ridwan Kamil dalam berbagai kegiatan sehariharinya, Ridwan Kamil lebih banyak menonjolkan informasi dirinya sebagai Wali Kota yang aktif berpartisipasi menjalankan tugasnya sebagai Wali Kota Bandung.

Hasil penelitian menunjukkan bahwa baik rute sentral maupun peripheral merupakan cara yang dapat menyukseskan penerimaan informasi baru. Kedua mekanisme ini kemudian membentuk intensi penerimaan pengguna dengan memodifikasi persepsi terhadap kegunaan dan sikap akanpesan tersebut. Namun, pemrosesan rute tersebut dipengaruhi oleh motivasi dan kemampuan mengelaborasi pesan yang diwakili oleh relevansi latar belakang target sasaran (followers).Pengguna dengan motivasi dan kemampuan mengelaborasi tinggi cenderung terpengaruh oleh rute sentral, sementara pengguna dengan elaborasi rendah cenderung menggunakan rute peripheral. Pengguna yang menggunakan rute sentral ini kemudian memiliki efek penerimaan yang lebih bersifat jangka panjang dibanding yang lain. 


\section{Analisis Isi Twitter Berdasarkan Personal Branding}

Gambar 3. menunjukkan bahwa status diri adalah jenis tulisan yang terbanyak atau dominan dalam jenis tulisan di akun twitter Ridwan Kamil, terlihat Ridwan Kamil lebih banyak menulis tentang dirinya dan kegiatankegiatan yang dilakukannya yaitu sebesar 58\% dibanding menulis saran dan kritik terhadap sesuatu.

Kecenderungan tulisan yang Ridwan Kamil buat lebih menunjukkan status diri mengenai kegiatan apa yang Ridwan Kamil lakukan, posisi di mana, dan apa saja yang dilakukan. Menulis saran juga cukup sering Ridwan Kamil lakukan yaitu sebesar 38\%.

Gambar 6 menunjukkan analisis isi yang dilakukan berdasarkan keunikan tulisan yang dibuat oleh Ridwan Kamil. Keunikan tulisan itu sendiri dibedakan atas tulisan yang inspiratif yaitu tulisan pesan yang bisa menjadi bahan perenungan pembaca (follower), dan tulisan yang berani kritis, yaitu tulisan yang berani menimbulkan kontra di masyarakat. Data pada diagram menunjukkan, berdasarkan analisis yang dilakukan pada isi twitter Ridwan Kamil terlihat bahwa dari 100 tweet yang dianalisis, hampir keseluruhan yaitu 94\% berisi tulisan yang inspiratif.

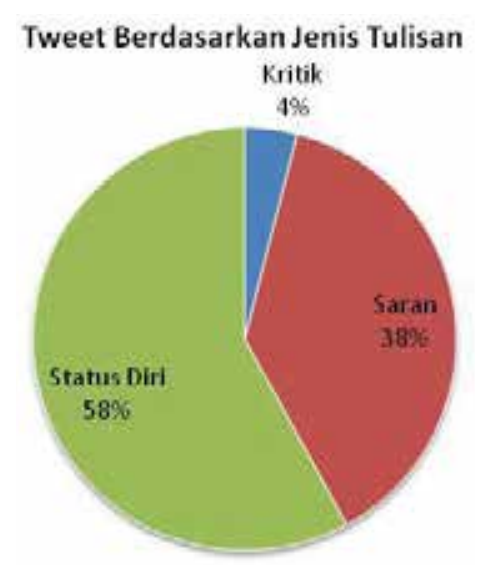

Gambar 6. Tweet berdasarkan jenis tulisan
Tweet Berdasarkan Keunikan Tulisan

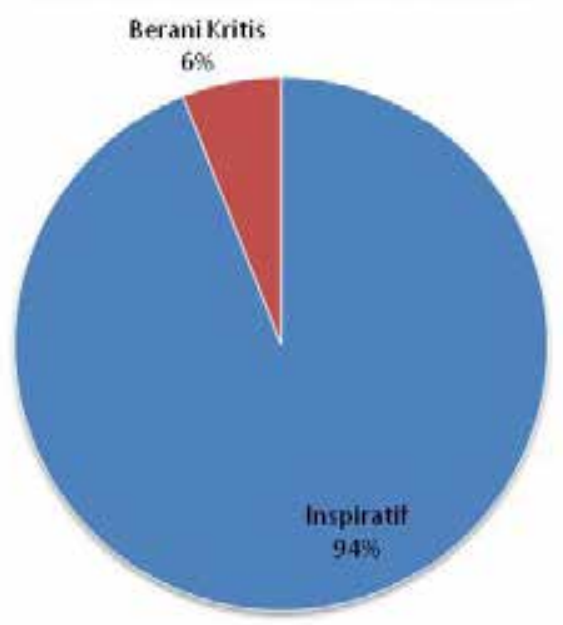

Gambar 7. Tweet berdasarkan keunikan tulisan

Gambar 7 menunjukkan arah tulisan yang dibedakan atas tulisan yang mengarah pada aktualisasi diri dan persuasif. Arah tulisan dari akun twitter Ridwan Kamil lebih ke arah aktualisasi diri dibandingkan persuasi, hal tersebut dilihat dari presentase yang di dapatkan dari analisis terhadap tulisannya. Aktualisasi diri didapatkan presentase sebesar 58\%, sedangkan persuasif sebesar $42 \%$.Aktualisasi yang dimaksudkan disini adalah mengarah pada informasi kegiatan subyek penelitian. Sedangkan persuasif mengarah pada pada upaya mempengaruhi, menghimbau, menyarankan sesuatu terhadap pihak lain.

\section{Tweet Berdasarkan Arah Tulisan}

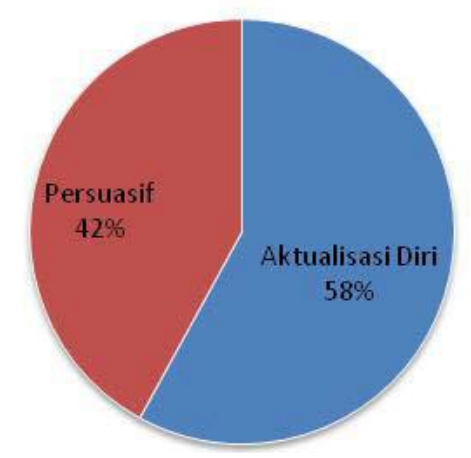

Gambar 8. Tweet berdasarkan Arah Tulisan 
Berdasarkan hasil penelitian ini, dapat dikatakan bahwa Ridwan Kamil lebih banyak menulis tentang aktualisasi diri, yang mengarah pada informasi kegiatan subyek penelitian dibandingkan tulisan persuasif. Citra dibentuk berdasarkan hasil persepsi dari stimulus yang diberikan dan pengalaman yang dirasakan sehingga membentuk kognisi yang berakhir pada sikap atau afeksi dan mempengaruhi motivasi individu untuk bertindak terhadap pesan.Citra memiliki kaitan dengan penyajian, dengan persepsi atau impresi publik yang dibentuk sebagai hasil dari tampilan tersebut.Hal ini kemudian yang membawa elemen persuasi dalam ide dari penyajian, dalam kaitannya dengan membentuk atau mempengaruhi persepsi atau impresi publik. Hal ini mengimplikasikan bahwa sumber penyampai pesan harus mengobservasi cara untuk mempengaruhi audiens untuk mendapat citra diri yang positif.

\section{Kemampuan Persuasi Lewat Argumen yang Kuat}

Teori Elaborasi Kemungkinan Model (ELM) mengasumsikan bahwa sikap dapat dibentuk atau diubah oleh dipengaruhi oleh kemampuannya untuk mempengaruhi pembujuk dan pesan persuasi. Kualitas pembujuk dan pesan dari kualitas akan mengarah pada pembentukan sikap yang diinginkan. Dari analisis tweet Ridwan Kamil didasarkan pada jenis argumen, Ridwan Kamil sebagai pembujuk kemampuan sendiri untuk mempengaruhi dan pesan persuasi disampaikan telah memberikan tanggapan atau komentar positif dari pengikut, dilihat dari jumlah argumen yang kuat dominan sebanyak $52 \%$.
Selain respon dan komentar positif, ada juga seorang pengikut yang memberikan tanggapan negatif, yang menunjukkan masih ada argumen yang lemah (argumen lemah) dalam akun twitter Ridwan Kamil (30\%). Temuan ini konsisten dengan asumsi teori Elaborasi Kemungkinan Model mampu memproses pesan persuasif dengan cara yang berbeda. Dalam situasi seseorang menilai pesan secara mendalam, berpikir hati-hati dan kritis, tetapi dalam situasi lain tidak satu hakim pesan saat yang lalu tanpa mempertimbangkan argumen mendasar dari isi pesan. Kemungkinan untuk memahami pesan persuasif secara mendalam tergantung pada bagaimana seseorang memproses pesan.

Hal ini diperkuat pada teori Kemungkinan Model Elaborasi bahwa argumen yang kuat adalah argumen yang menciptakan respon positif di penerima pikiran kognisi juga telah positif dipengaruhi keyakinan mereka dengan pandangan argumen pemberi atau mereka yang mengambil.Dalam hal ini Ridwan Kamil sebagai memberikan argumen mampu menciptakan respon positif terhadap kognisi follower melalui pesan persuasi yang disampaikan di akun twitter-nya.

Fakta yang tak terbantahkan dalam penelitian ini adalah jumlah besar pengikut (follower) subjek penelitian akun twitter. Terbukti dengan jumlah pengikut di akun twitter-nya Ridwan Kamil besar, mencapai 1,2 juta pengikut. Meskipun jumlah pengikut di twitter bukanlah segalanya, tetapi seseorang yang populer di media sosial tidak berarti adalah influencer yang baik. Seorang pengguna Twitter mungkin 
memiliki ribuan pengikut, tapi itu tidak berarti itu bisa dijadikan patokan jika ia juga bisa mempengaruhi pengikutnya.

Jumlah pengikut menunjukkan bahwa itu menjadi kekuatan tersendiri. Ridwan Kamil mampu mempengaruhi para pengikutnya untuk melakukan tindakan di dunia nyata dengan memindahkan mereka melalui media sosial. Pertama, apa yang dilakukan Ridwan Kamil sesuai dengan karakteristik media sosial modern, yaitu di tweeted ada keterbukaan informasi yang disampaikan kepada penonton. Kedua, dalam dialog dan twitter komunikasi follower dengan pandangan jumlah besar tweet dan favorit. Ketiga, adanya hubungan interaktif dengan followersnya membuat Ridwan Kamil bisa menjadi mesin untuk followers-nya. Keempat, multi pendapat, yang berarti twitter yang dapat membentuk opini dari para pengikutnya secara bebas. Dari data di atas dapat dikatakan bahwa personal branding terbentuk melalui twitter memang telah dibentuk oleh Ridwan Kamil.

Tematik Partisipasi dan Keterlibatan Ridwan Kamil dengan Publik melalui Twitter

Menulis tema partisipasi adalah tweet tema yang paling (46\%) ditulis oleh Ridwan Kamil di akun Twitter-nya. Tweet kategori partisipasi ini berisi tulisan-tulisan tentang keterlibatan Ridwan Kamil dalam sejumlah kegiatan, baik itu kegiatan negara, serta kegiatan sosial dan keagamaan. Hal ini menunjukkan bahwa, keterlibatan Ridwan Kamil di sejumlah kegiatan yang tidak hanya dapat dilihat pada menulis tweet, tetapi juga dalam tindakan atau tindakannya.

Partisipasi yang dimaksud di sini termasuk dalam apa yang disebut dialog dan komunikasi, di mana membentuk hubungan yang sepenuhnya dalam bentuk komunikasi, seperti antara merek pribadi dengan publik. Dalam hal ini Ridwan Kamil adalah merek sendiri, sementara pengikut bisa disebut publik.Antara merek dan media umum komunikasi melalui twitter. Intensitas komunikasi adalah apa yang menyebabkan hubungan antara merek dan masyarakat untuk membentuk jaringan hubungan. Jaringan hubungan ini dapat terjadi antara individu atau kelompok individu atau perwakilan yang didorong oleh individu. Artinya dalam bentuk personal branding melalui twitter, selain menulis diperlukan yang menunjukkan tindakan nyata juga diperlukan untuk partisipasi dalam masyarakat.

Berdasarkan Elaboration Likelihood Model, baik faktor situasional maupun disposisional dapat mempengaruhi sejauhmana suatu sikap dibentuk melalui pemikiran atas isu-isu yang relevan. ELM mengemukakan bahwa level persuasi yang terjadi berdasarkan motivasi individu dan kemampuan untuk berpikir dan mengevaluasi komponen dari informasi. Persuasi kemudian dapat dicapai dengan menekankan dua rute berbeda terhadap perubahan sikap yaitu central route dan periphral route.

ELM digunakan sebagai teori dasar untuk menilai kualitas informasi terhadap kepercayaan pengguna sosial media, maka kualitas argumen dan kredibilitas sumber memiliki kesan positif dalam pembentukan kesan. Rute periferal digunakan dalam hal followers memproses informasi di twitter untuk menentukan harus menerima atau menolah satu informasi. Sementara rute sentral digunakan dalam hal followers 
memproses informasi di twitter untuk menentukan harus memercayai satu informasi atau tidak. Ketika elaborasi rendah, individu tidak berpikir banyak mengenai konten pesan.Sebaliknya, mereka menggunakan elemen non konten yang terasosiasi dengan pesan sebagai dasar pembentukan sikap.

Rute periferal menilai bahwa perubahan sikap diakibatkan oleh sikap yang diasosiasikan oleh objek baik berupa petunjuk postif maupun negatif atau seseorang menggunakan aturan pengambilan keputusan sederhana untuk mengevaluasi suatu komunikasi.Petunjuk dan aturan pengambilan keputusan ini dapat membentuk sikap atau memungkinkan seseorang memutuskan posisi sikap mana yang harus diadopsi tanpa harus terlibat dalam pemikiran terhadap isu yang relevan. Dalam rute ini, keterlibatan bersifat rendah, individu mungkin tidak mau atau tidak mampu menggunakan banyak usaha untuk memproses pesan atau disebut dengan low elaboration situation.

\section{Personal Branding yang Kuat}

Merek atau brand diri sendiri, dalam penggunaan twitter juga bisa dibentuk melalui tulisan-tulisan yang terdapat dalam akun twitter orang tersebut. Hal ini dapat dilihat dari hasil penelitian menunujukan bahwa arah dari menulis akun twitter Ridwan Kamil lebih ke arah aktualisasi diri (58\%) dari persuasi. Aktualisasi disebutkan di sini mengacu pada kegiatan informasi dari subjek penelitian. Kegiatan ini bukan hanya tentang kegiatan pribadi, tetapi juga berkaitan dengan pelayanan dan kegiatan sosial. Personal Branding adalah proses yang membutuhkan keterampilan, kepribadian dan karakteristik unik dari seseorang dan kemudian membungkusnya ke dalam identitas yang memiliki kekuatan lebih dari kompetisi.

Personal branding merupakan sesuatu yang kongkrit dan mudah didefinisikan orang lain. Secara global telah dikenal beberapa figure yang memiliki personal branding yang sangat baik, yaitu Michael Jordan, yang secara langsung berhubungan dengan olahraga basket, Oprah Winfrey dipandang sebagai presenter televisi terpercaya. Dengan kata lain, personal branding juga khusus. Seseorang yang terkait dengan hal-hal tertentu karena dia spesialisasi.Di ranah Twitter, setiap tweet yang menciptakan persepsi di benak pengikut. Orang-orang yang berada di rasa twitter humor, persepsi yang terbangun di benak orang lain adalah orang-orang kami yang menyenangkan. Jika kita ingin berbagi informasi tentang kesehatan, kemudian bangun di pikiran orang lain adalah bahwa kita adalah orang yang ahli di lapangan. Merek tidak hanya perusahaan atau organisasi atau produk, merek juga dapat dipersonifikasikan. Merek adalah esensi atau menjanjikan untuk dikirimkan atau dirasakan.

Personal branding dapat membentuk salah satu ciri khas dari seseorang yang membedakannya dari orang lain. Ini bisa menjadi ciri khas dari keterampilan, keahlian, atau penampilan seseorang. Dalam penelitian ini, unsur pembeda dilihat dari keunikan tulisan yang dibuat oleh Ridwan Kamil. Keunikan dari artikel itu sendiri tulisan inspiratif dibedakan menulis pesan yang bisa menjadi bahan refleksi pembaca (follower), dan menulis berani kritis, yaitu tulisan yang berani dan kritis, yang berani untuk memecahkan hambatan komunikasi yang ada di masyarakat. Dari hasil 
penelitian, subyek penelitian (Ridwan Kamil) telah menerapkan konsep diferensiasi. Tulisantulisan dari subjek yang memiliki karakteristik unik atau perbedaan dibandingkan dengan tulisan pemilik akun twitter lainnya, yang seperti telah dijelaskan di atas bahwa tulisan pada subjek cenderung menulis inspirasi.

Terkait diferensiasi, proses perumusan dibagi tiga dimensi, yaitu dimensi Konten, yang menunjukkan perbedaan dalam nilai "apa" yang ditawarkan kepada pelanggan.Berikut unsur-unsur membedakan diri dari kompetisi didasarkan pada “apa” yang Anda tawarkan.Ini adalah bagian nyata dari diferensiasi. Konteks dimensi kedua, dimensi yang menunjukkan "bagaimana" untuk menawarkan nilai kepada pelanggan. Berikut adalah membedakan diri dari pesaing, yaitu bagaimana kita menawarkan nilai kepada pelanggan. Ini adalah intangible diferensiasi. Infrastruktur dimensi ketiga, yaitu memungkinkan faktor (enabler) menyadari diferensiasi konten dan konteks. Dimensi ini menunjukkan perbedaan terhadap pesaing berdasarkan kemampuan teknologi, kemampuan sumber daya manusia (SDM), dan kepemilikan fasilitas untuk mendukung menciptakan diferensiasi konten dan konteks di atas.

\section{Simpulan}

Pengembangan dan penggunaan media baru, khususnya media sosial dalam hal ini adalah twitter semakin luas. Salah satu penggunaan media baru ini adalah untuk membangun personal branding. Oleh karena itu, latar belakang penelitian ini, adalah karena melihat jumlah penggunaan dan penggunaan media sosial (social media), terutama twitter digunakan untuk membentuk personal branding.
Hasil penelitian menunjukkan bahwa isi twitter Ridwan Kamil lebih utama bertema mengenai partisipasi berupa acara atau kegiatan beliau sehari-hari. Pemilihan seputar tema isi twitter dapat digunakan untuk menarik perhatian followers guna membentuk personal branding Ridwan Kamil. Pembentukan personal branding dibentuk melalui tulisan yang dibuat dalam twitter dengan tema yang dekat dengan kehidupan followers. Pembentukan personal branding dilihat dari tema penulisan, retweet dan nomor favorit, jenis tulisan, keunikan menulis dan arah penulisan. Ini berarti dalam bentuk personal branding diperlukan tema yang menunjukkan partisipasi akun penulis twitter dan menunjukkan aktualisasi dirinya, serta mampu menulis dengan gaya yang unik dan inspiratif, sehingga untuk menarik perhatian banyak orang dan lebih jauh lagi dikenal di dunia media sosial dan mendapatkan banyak pengikut.

Penelitian ini hanya difokuskan pada positioning, diferensiasi dan merek yang dimiliki oleh seseorang dalam bentuk personal branding. Oleh karena itu, diperlukan penelitian lain melihat proses personal branding terdiri dari faktor-faktor lain di luar konsep. Pembentukan personal branding diperlukan oleh seseorang tidak hanya melalui tulisan-tulisan yang disampaikan melalui media, tetapi juga kebutuhan untuk partisipasi tindakan nyata dan keterlibatan dalam kehidupan masyarakat. Pentingnya membentuk personal branding sehingga individu semakin diakui oleh tujuan misi umum dan visi dicapai adalah penting terutama bagi praktisi politik. 


\section{Daftar Pustaka}

Anggraeni, Novi, Mukarto Siswoyo, dan Farida Nurfalah. (2014). Strategi Public Relations dalam Mendukung pemasaran Pembangkit Listrik Nasional (PLN).Jurnal Komunikasi ASPIKOM, Volume 2 Nomor 3, Juli 2014, hal.206-220.

Bhattacherjee, Anol, and Clive Sanford. (December 2006).Influence Process for Information Technology Acceptance: An Elaboration Likelihood Model. MIS Quarterly Vol. 30 No. 4, hal. 805-825.

Databoks (22 November 2016). Indonesia Pengguna Twitter Terbesar Ketiga di Dunia.http://databoks.katadata.co.id/ datapublish/2016/11/22/indonesiapengguna-twitter-terbesar-ketiga-di-dunia, diakses 9 Juni 2017.

Flew (2005).New Media: An Introduction, 2nd Edition. New York: Oxford University Press.

Ginting, Magdalena Lestari. (2013). Pengaruh Interaktivitas Akun Twitter Perusahaan terhadap Efektivitas Komunikasi (Studi Analisis Isi Akun Twitter Perusahaan Samsung dalam Interaktivitasnya Mempengaruhi Penjualan). Surakarta: Universitas Sebelas Maret Surakarta.

Griffin, E.M.(2003). A First Look at Communication Theory. $5^{\text {th }}$ edition. Boston:McGraw Hill. (2010). A First Look at Communication Theory. $8^{\text {th }}$ edition. Boston:McGraw Hill.

Hadi, Ido Prijana. (2011).Pengguna Media Interaktif Sebagai Kenyataan Maya: Studi Resepsi Khalayak Suarasurabaya. net Sebagai Media Interaktif. Jurnal Komunikasi ASPIKOM, Volume 1, Nomor 2, Juli 2011, hal. 231-244.

Juju, Dominikus, dan Feri Sulianta. (2010). Branding Promotion with Social Networks. Jakarta:PT. Elex Media Komputindo.
Kertajaya, Hermawan.(2004). PositioningDifferensiasi-Brand; Memenangkan Persaingan dengan Segitiga. Jakarta: PT Gramedia Pustaka Utama. (2010). Grow with Character the Story. Jakarta: PT Gramedia Pustaka Utama.

Krippendorff, Klauss. (2006). Content Analysis: An Introduction to Methodology, 3rd Edition. Thousand Oaks, CA:Sage Publications Inc.

Kriyantono, Rachmat. (2007). Teknik Praktis Riset Komunikasi. Jakarta: Kencana.

Lestari, Gita. (2010). Evaluasi dan Perancangan Pesan dalam Iklan Jangan Merokok untuk Siswi SMA Melalui Metode Elaboration Likelihood Model.http://lontar.ui.ac. id/detail.jsp?id=20340723, diakses 28 Desember 2015.

Lien, N. (2001).Elaboration Likelihood Model in Consumer Research: A Review. Journal of Consumer Research.Volume 11 No.4.hal. 301-310.

McNally, David, and Karl D. Speak. (2002). Be Your Own Brand. San Fransisco: Berret Koehler Publisher, Inc.

McQuail.(2011). Teori Komunikasi Massa. Jakarta: Erlangga.

Pee, Loo Geok. (2012). Trust of Information on Social Media: An Elaboration Likelihood Model. International Conference on Information Resource Management (CONF-IRM)

Syaifuddin.(2013). Microblogging Sebagai Pembentuk Personal Branding (Analisis Isi Microblogging dalam Membentuk Personal Branding Akun Twitter Fahira Idris).JMA Vol. 18 No. 2 Oktober November 2013, hal.116-140.

Terence, Shimp A. (2003). Periklanan Promosi, Aspek Tambahan, Komunikasi Pemasaran Terpadu.Diterjemahkan oleh Deyvani Sahrial dan Arikasani. Jakarta: Erlangga. 